\title{
DOMESTIC WASTEWATER TREATED BY ANAEROBIC BAFFLED REACTORS AND GRAVEL FILTERS AS A RESOURCE TO BE USED IN AGRICULTURE
}

Ivette Echeverría, Laura Machicado, Oliver Saavedra, Ramiro Escalera, Gustavo Heredia y Renato Montoya

\begin{abstract}
Due to limited availability of clean water, treated wastewater is an important resource to reduce water demand through its reuse. In Bolivia, one of the most common practices is the use of wastewater for crop irrigation. Wastewater Treatment Plants (WWTP) must adequate their processes so their effluents are safe for irrigation and for the environment. The intermediate city of Tolata, located at 2720 meters above sea level operates a WWTP with a solids removal pretreatment followed by an Anaerobic Baffled Reactors (ABR) and series of horizontal and vertical gravel filters. The objective of this study is to evaluate its efficiency and determine the potential of the treated effluent for crop irrigation. To assess water quality parameters a series of monitoring campaigns were carried out from August to December 2018. The average concentrations found in the WWTP affluent are as follows: $396 \pm 289$ $\mathrm{mg}-\mathrm{BOD}_{5} / \mathrm{l}, 795 \pm 262 \mathrm{mg}-\mathrm{COD} / \mathrm{l}, 361 \pm 113 \mathrm{mg}-\mathrm{TSS} / \mathrm{l}, 66.0 \pm 38.9 \mathrm{mg}-\mathrm{N}-\mathrm{NH}_{3} / \mathrm{l}, 11.8 \pm 2.2 \mathrm{mg}-\mathrm{P} / \mathrm{l}$ and $2.73 \pm 1.13$ $\mathrm{m}-\mathrm{S} / \mathrm{cm}$ for EC. The concentrations found in the effluent on average are: $18 \pm 12 \mathrm{mg}-\mathrm{BOD}_{5} / \mathrm{l}, 95 \pm 61 \mathrm{mg}-\mathrm{COD} / \mathrm{l}, 18$ $\pm 10 \mathrm{mg}-\mathrm{TSS} / \mathrm{l}, 41.7 \pm 26.5 \mathrm{mg}-\mathrm{N}-\mathrm{NH}_{3} / \mathrm{l}, 8.3 \pm 2.2 \mathrm{mg}-\mathrm{P} / \mathrm{l}$ and $2.35 \pm 0.75 \mathrm{~m}-\mathrm{S} / \mathrm{cm}$ for EC. The overall efficiencies of the WWTP obtained are: $95 \%$ of $\mathrm{BOD}_{5}, 88 \%$ of total COD, $95 \%$ of TSS, 37\% of N-NH3, and $30 \%$ of P. According to these results, it is advisable to restrict irrigation to tall stemmed crops, grass and fodder that have moderate tolerance to salinity and are not eaten raw or without further processing to reduce risks associated with health. In order to use the treated effluent for irrigation of vegetables or other products that are eaten raw, this WWTP needs to implement a disinfection process.
\end{abstract}

Keywords: Anaerobic Baffled Reactor, Wastewater, Performance, Reuse, Irrigation, Gravel Filters, WWTP Evaluation, Bolivia, Sustainability.

DOI: 10.23881/idupbo.019.1-4i 